\title{
Integrated Nutrient Management on Soil Properties and Nutrient Uptake by Red Onion
}

\author{
Emmanuel Kwada Kwaghe, Abdullahi Muhammad Saddiq, Rejoice Ibrahim Solomon*, \\ Salihu Ardo Musa
}

Department of Soil Science, School of Agriculture and Agricultural Technology, Modibbo Adama University of Technology, Yola. Adamawa State, Nigeria

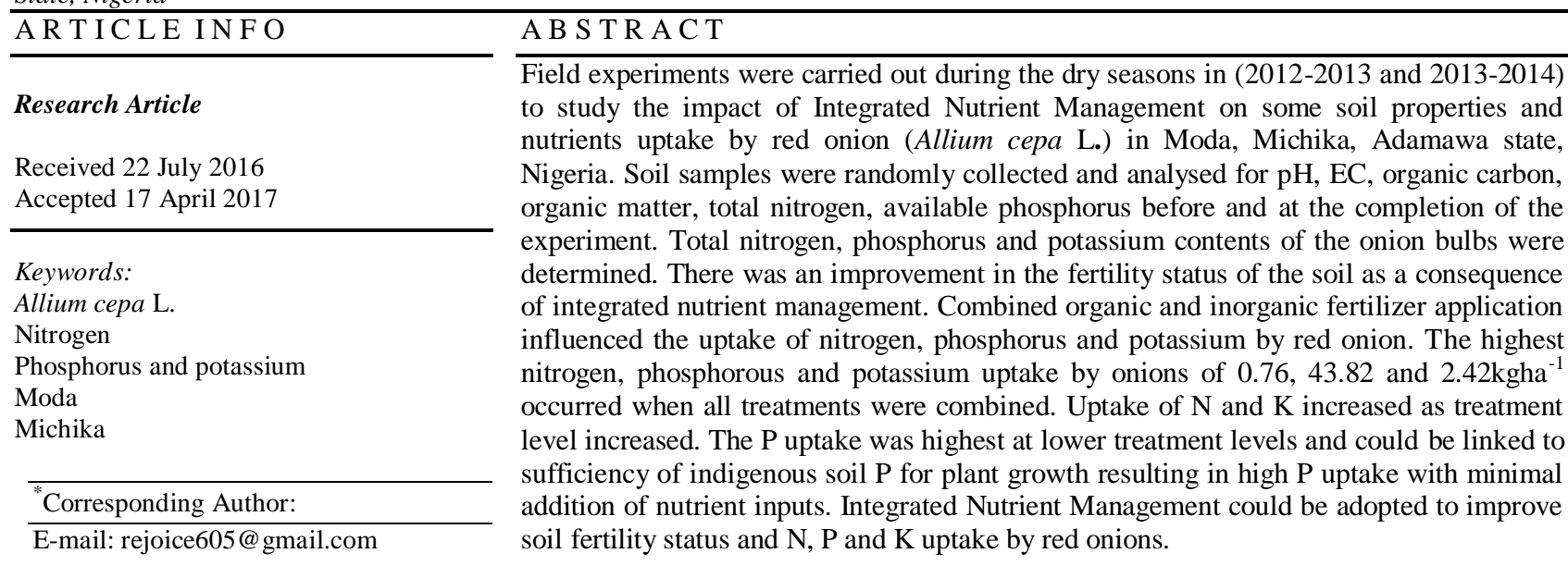

DOI: https://doi.org/10.24925/turjaf.v5i5.471-475.927

\section{Introduction}

The amount of nutrient required by plants for their growth and development is determined to an extent by their genetic make-up (Epstein, 1972; Rengel, 2002). However, other physical, chemical and biological factors determine availability and uptake of the nutrients. Before the advent of chemical fertilizers, manures were used as a primary source of nutrients in production (Kwaghe et al., 2015). In addition to supplying nutrients to soil, manure improves soil health by increasing soil organic matter and promoting beneficial organism populations. Incorporating manure into a field helps improves soil structure and water holding capacity thereby, reducing soil erosion (Lal, 1985).

Onion (Allium cepa L.) production and quality are often low due to inappropriate agronomic practices; nutrient supply, weed control, and fertilizer rates (Lado, 2008). Red onion varieties typically have red skin and red and white flesh, are very crisp but do not store well. Although the amount of nutrients needed by the plant depends on its genotype (Rengel, 2002), some crop varieties have the capacity to exhibit high degree of efficiency in nutrient uptake and which can increase total yield (Rengel, 1993). In some instances excessive inorganic fertilizers are required to achieve higher yields (Steward et al., 2008). Application of chemical fertilizers alone generate deleterious effects to the environment and human health and needs to be replenished in every cultivation season because the commonly used synthetic $\mathrm{N}, \mathrm{P}$ and $\mathrm{K}$ fertilizer are rapidly lost by evaporation or leaching in drainage water leading to environmental pollution (Aisha et al., 2007). Continuous use of inorganic fertilizer affects soil structure and creates nutrient imbalances especially in relation to micronutrients (Sillampaa, 1992). Integrated Nutrient Management (INM) could be an option to improve soil structure and microbial biomass (Suresh et al., 2005). and sustainable crop production (Woomer and Swift, 1994).

Sustainable soil nutrient-enhancing strategies involve the appropriate use and management of inorganic and organic nutrient sources in ecologically sound production systems. The basic concept underlying the principle of integrated management is to maintain or adjust plant nutrient supply to achieve a given level of crop production by optimizing the benefits from possible sources of plant nutrients. Integrated Nutrient Management reduces the inorganic fertilizer requirements, to enhance nutrient use efficiency and maintains soil quality in-terms of physical, chemical and biological properties. This study was undertaken to evaluate the impact of Integrated Nutrient Management on soil properties and nutrient uptake by red onions. 


\section{Materials and Methods}

The experiment was conducted at Moda in Michika local government area of Adamawa state located between latitudes $10^{\circ} 36^{\prime}-10^{\circ} 40^{\prime} \mathrm{N}$, longitudes $13^{\circ} 21-13^{\circ} 35^{\prime} \mathrm{E}$. The experiment consisted of 9 treatments; $\mathrm{T} 1=141.3 \mathrm{~kg}$ $\mathrm{ha}^{-1} \mathrm{~N}$ from Urea, $\mathrm{T} 2=141.3 \mathrm{~kg} \mathrm{ha}^{-1} \mathrm{~N}$ from Urea +250 $\mathrm{kgha}^{-1} \mathrm{P}$ from Single super phosphate (SSP), T3 = 5500 $\mathrm{kg} \mathrm{ha}^{-1}$ Poultry Manure, T4 = $5500 \mathrm{kgha}^{-1}$ Sheep Manure, T5 = $5500 \mathrm{~kg} \mathrm{ha}^{-1}$ Cow dung, T6 ha ${ }^{-1} \mathrm{~N}+120 \mathrm{~kg} \mathrm{ha}^{-1} \mathrm{P}+$ $2750 \mathrm{~kg} \mathrm{ha}^{-1}$ Poultry Manure, $\mathrm{T} 7=70.65 \mathrm{~kg} \mathrm{ha}^{-1} \mathrm{~N}+125$ $\mathrm{kg} \mathrm{ha}^{-1} \mathrm{P}+2750 \mathrm{~kg} \mathrm{ha}^{-1}$ Sheep Manure, T8 $=70.65 \mathrm{kgha}^{-1}$ $\mathrm{N}+125 \mathrm{~kg} \mathrm{ha}^{-1} \mathrm{P}+2750 \mathrm{~kg} \mathrm{ha}^{-1}$ cow dung, $\mathrm{T} 9=35.33$ $\mathrm{kg} \mathrm{ha}^{-1} \mathrm{~N}+62.50 \mathrm{~kg} \mathrm{ha}^{-1} \mathrm{P}+1375 \mathrm{kgha}^{-1}$ Poultry +1375 $\mathrm{kg} \mathrm{ha}^{-1}$ sheep manure $+1375 \mathrm{~kg} \mathrm{ha}^{-1}$ cow dung arranged in a Randomized Complete Block Design replicated 3 times. Each replication contained 9 plots giving a total of 27 plots with each plot measuring $3 \times 3 \mathrm{~m}$.

The soils of the study area were sandy loam in texture. Composite soil sample were taken from a depth of 0 to 20 $\mathrm{cm}$ before and at the completion of the experiment and were bulked for laboratory analysis. Soil sample were airdried, crushed using pestle and mortar and sieved through a $2 \mathrm{~mm}$ sieve mesh. The sieved samples were used for routine analysis at the Modibbo Adama University of Technology Yola, Soil Science Department Laboratory. The soil physical and chemical properties; particle size analysis, bulk density, percentage porosity was determined as described by Jaiswal (2004). Soil pH, electrical conductivity (EC), effective cation exchange capacity (ECEC), organic carbon and total nitrogen were determined as described by Jaiswal (2004) Available phosphorus was determined using the Bray I method as described by Bray and Kurtz (1945).

Onion seeds obtained from Institute of Agricultural Research, Samaru, Zaria were broadcasted on a nursery bed of $2 \times 2 \mathrm{~m}$ and covered with light layer of soil and mulched. Watering was done twice (morning and evening) to when the seedlings were due for transplanting at six weeks after planting; when the seedlings were about $10-12 \mathrm{~cm}$ of height. The pencil sized seedlings were transplanted to the experiment site at a spacing of $30 \mathrm{~cm}$ within row and $30 \mathrm{~cm}$ between rows in November, 2012 and 2013.

The organic fertilizers (poultry droppings, cow dung and sheep manure) were applied at land preparation, while the nitrogen supplied by urea was applied in 2 equal doses at 3 and 6 (WAP) using broadcasting method. During the growth period, weeds were controlled manually with hoe on regular bases. Surface irrigation method was used in conveying water into each furrow twice a week. The irrigation water discharges into the furrow were computed and the depth of 3 inches per week maintained and monitored using a stop watch. However, water application was cut back when the leaves started drying to prevent the bulbs from rotting. The timed volume-container head method (bucket system) was employed during each irrigation scenario. In calculating the amounts of water applied to required depth, the flow rate was estimated using Trimmer (1994) formula:

$$
\mathrm{D}=\mathrm{V} / \mathrm{T}
$$

Where;

$\mathrm{D}=$ Discharge rate (liters/seconds),

$\mathrm{V}=$ Volume of the container (liters) and

$\mathrm{T}=$ Time (seconds).

Six plants from the centre of plots were sampled to avoid border effect. Plant samples were kept in a brown paper envelopes, oven- dried at $60^{\circ} \mathrm{C}$ using forced air oven for 48 hours after which they were milled and passed through a $2 \mathrm{~mm}$ mesh sieve for uptake studies. Nitrogen, $\mathrm{P}$ and $\mathrm{K}$ uptake were carried out as described by Jaiswal (2004).

Data collected were analysed statistically using the Generalized Linear Model procedure of Statistical Analysis System (1999) in a Randomized Complete Block Design. Duncan's Multiple Range Test was used to separate means that were significantly different.

\section{Results and Discussion}

The soils of Michika are sandy loam in texture (Table 1). Bulk density, particle density and soil porosity fall within the value of mineral soils (Brady and Weil, 2008). The increase in porosity in the second year could be due to residual effects of organic fertilizers of the first year.

Ogbodo et al. (2009) reported increased soil total porosity and soil moisture content in response to cow manure and poultry litter application when compared to urea.

The soil $\mathrm{pH}$ was slightly acidic. Which may in part attributed to higher sand proportion which allows leaching of basic cations to sub-surface horizons of the soil and fertilization practices particularly use of $\mathrm{NH}_{4} \mathrm{SO}_{4}$ fertilizers. Wortman et al. (2009) reported that repeated use of $\mathrm{NH}_{4}{ }^{+}$based acid forming fertilizer, leaching of $\mathrm{NO}_{3}{ }^{-} \mathrm{N}$ and plant removal of cation eventually caused top soil acidity. This $\mathrm{pH}$ value is acceptable for onion production. Messiaen and Rouamba (2004) reported that onion and shallots grows on any soil with $\mathrm{pH}$ above 5.6 but with adequate calcium nutrition which is essential for good vegetative development and disease tolerance. Onion does best if the soil $\mathrm{pH}$ is between 5.5 and 6.5 (National Gardening Association, 2015). The electrical conductivity (EC) indicated low salt concentration in the first year. There was a significant increase in EC value in the second year (Table 1). This may be partly due to the addition of organic matter and possibly the irrigation water. Podmore (2009) reported irrigation water as a source of soil salinization and causes of irrigation salinity could be leakages and ground water recharge causing the water table to rise bringing salts to the plant root zone.

Soil organic carbon content of the soil decreased in the second year (Table 1). And this may be due to increased activities of microorganisms created by favourable environmental condition. Trehan (1997) reported reduction in organic carbon content in subsequent seasons and linked the difference in carbon content of soil to different rates of oxidation of organic matter by microbes. Alexander (1971) and Havlin et al. (1999) reported that 
adding organic matter to soil s positively affects activities of soil organisms and hastens the decomposition of the organic materials. The increase in available nitrogen $\mathrm{N}$ in the second year may be due to integrated application of organic and inorganic fertilizers, increasing total N. Mirza et al. (2010) reported that application of NPK with organic manure resulted in greater nutrients availability especially N.

Available phosphorus (AVP) content of the soil was moderate. The available phosphorus content of the soil decreased by about $5 \%$ in the subsequent season (Table 1). This may be attributed to plant uptake as immobilization as a result of increased microbial activity. Similar results were reported by Sanchez (1997). He reported nutrients mining by plants and immobilization of $\mathrm{P}$ due to increased microbial activity to be the dominant factors responsible for reduced $\mathrm{P}$ availability on cultivated lands..
Misra and Das (2000) reported decreased available P from the $15^{\text {th }}$ to $45^{\text {th }}$ day of incubation and attributed reduced availability to increased microbial immobilization of $\mathrm{P}$ into their cell structure. Exchangeable bases marginally increased in the second year (Table 1). This could be due to improved soil fertility as a result of fertilizer application. Lower total exchangeable acidity of the soil in the second year could be attributed to the stabilizing effect of the organic manure with the acid forming ions $\mathrm{H}^{+}$and $\mathrm{Al}^{3+}$ which could raise the $\mathrm{pH}$. The cation exchange capacity increased marginally in the second year (Table 1). These results indicate improved soil fertility as a result of treatment.

The highest nitrogen uptake was recorded by the integrated application of poultry manure + sheep manure + cow dung + inorganic fertilizer (Table 2 and 3).

Table 1 Some physical and chemical properties of soil from the $0-20 \mathrm{~cm}$ of the experimental site

\begin{tabular}{|c|c|c|}
\hline Parameters & $2012 / 2013$ & $2013 / 2014$ \\
\hline Particle density $\left(\mathrm{gcm}^{-3}\right)$ & 2.17 & 2.94 \\
\hline Bulk density $\left(\mathrm{gcm}^{-3}\right)$ & 1.45 & 1.47 \\
\hline Porosity $(\%)$ & 33 & 50 \\
\hline Sand $(\%)$ & 53.80 & 56.80 \\
\hline Silt $(\%)$ & 28.00 & 16.20 \\
\hline Clay $(\%)$ & 18.20 & 27.00 \\
\hline Texture & Sandy loam & Sandy loam \\
\hline $\mathrm{pH}(1: 2$ soil to water $)$ & 6.22 & 6.25 \\
\hline $\mathrm{EC}\left(\mathrm{dSm}^{-1}\right)$ & 0.006 & 0.018 \\
\hline Organic carbon $(\%)$ & 1.18 & 1.22 \\
\hline Organic matter $(\%)$ & 2.03 & 2.10 \\
\hline Available N (\%) & 0.036 & 0.032 \\
\hline Available P (mg.kg $\left.{ }^{-1}\right)$ & 16.10 & 15.40 \\
\hline \multicolumn{3}{|l|}{ Exchangeable bases $\left[\mathrm{cmol}(+) \mathrm{kg}^{-1}\right]$} \\
\hline $\mathrm{Ca}^{2+}$ & 3.40 & 3.30 \\
\hline $\mathrm{Mg}^{2+}$ & 0.20 & 0.20 \\
\hline $\mathrm{Na}^{+}$ & 0.67 & 1.10 \\
\hline $\mathrm{K}^{+}$ & 0.15 & 0.15 \\
\hline Total exchangeable bases $\left[\mathrm{cmol}(+) \mathrm{kg}^{-1}\right]$ & 4.42 & 4.75 \\
\hline $\mathrm{H}^{+}\left[\mathrm{cmol}(+) \mathrm{kg}^{-1}\right]$ & 0.50 & 0.40 \\
\hline $\mathrm{Al}^{3+}\left[\mathrm{cmol}(+) \mathrm{kg}^{-1}\right]$ & 1.00 & 0.90 \\
\hline Total exchangeable acidity $\left[\mathrm{cmol}(+) \mathrm{kg}^{-1}\right]$ & 1.50 & 1.30 \\
\hline Effective cation exch. capacity $\left[\mathrm{cmol}(+) \mathrm{kg}^{-1}\right]$ & 5.92 & 6.05 \\
\hline Percentage base saturation $(\%)$ & 74.32 & 78.5 \\
\hline
\end{tabular}

Table 2 Effect of organic and inorganic fertilizers on uptake of N, P, and $\mathrm{K}$ by onion bulbs in the first year

\begin{tabular}{l|ccc}
\hline \multicolumn{1}{c|}{ Treatment } & $\mathrm{N}\left(\mathrm{kg} \cdot \mathrm{ha}^{-1}\right)$ & $\mathrm{P}\left(\mathrm{kg} \cdot \mathrm{ha}^{-1}\right)$ & $\mathrm{K}\left(\mathrm{kg} \cdot \mathrm{ha} \mathrm{a}^{\mathrm{-1}}\right)$ \\
\hline T1 & $0.36^{\mathrm{cd}}$ & $33.35^{\mathrm{ab}}$ & $1.92^{\mathrm{cd}}$ \\
T2 & $0.27^{\mathrm{d}}$ & $43.82^{\mathrm{a}}$ & $1.95^{\mathrm{c}}$ \\
T3 & $0.41 \mathrm{~b}^{\mathrm{cd}}$ & $12.25^{\mathrm{c}}$ & $2.42^{\mathrm{a}}$ \\
T4 & $0.47^{\mathrm{bc}}$ & $11.38^{\mathrm{c}}$ & $2.08^{\mathrm{bc}}$ \\
T5 & $0.53^{\mathrm{b}}$ & $9.79^{\mathrm{c}}$ & $1.74^{\mathrm{e}}$ \\
T6 & $0.43^{\mathrm{bcd}}$ & $22.40^{\mathrm{bc}}$ & $1.76^{\mathrm{de}}$ \\
T7 & $0.55^{\mathrm{b}}$ & $39.63^{\mathrm{a}}$ & $2.15^{\mathrm{b}}$ \\
T8 & $0.52^{\mathrm{bc}}$ & $15.31^{\mathrm{c}}$ & $2.39^{\mathrm{a}}$ \\
T9 & $0.76^{\mathrm{a}}$ & $14.58^{\mathrm{c}}$ & $1.93^{\mathrm{cd}}$ \\
Mean & 0.48 & 22.50 & 2.04 \\
SE & 0.09 & 8.91 & 0.10 \\
\hline
\end{tabular}

Values followed by the same letters in columns are not significantly different $(\mathrm{P}<0.05)$ Generalized Linear Model Procedure of Statistical analysis system (1999). 
Table 3 Effect of organic and inorganic fertilizers on N, P, and K uptake in onion Bulbs in the second year

\begin{tabular}{l|ccc}
\hline \multicolumn{1}{c|}{ Treatment } & $\mathrm{N}\left(\mathrm{kg} \cdot \mathrm{ha}^{-1}\right)$ & $\mathrm{P}\left(\mathrm{kg} \cdot \mathrm{ha}^{-1}\right)$ & $\mathrm{K}\left(\mathrm{kg} \cdot \mathrm{ha}^{-1}\right)$ \\
\hline T1 & $0.39^{\mathrm{bc}}$ & $44.99^{\mathrm{a}}$ & $2.03^{\mathrm{ab}}$ \\
T2 & $0.38^{\mathrm{bc}}$ & $33.27^{\mathrm{abc}}$ & $2.00^{\mathrm{abc}}$ \\
T3 & $0.27^{\mathrm{c}}$ & $11.89^{\mathrm{d}}$ & $1.63^{\mathrm{cd}}$ \\
T4 & $0.56^{\mathrm{ab}}$ & $18.36^{\mathrm{cd}}$ & $2.07^{\mathrm{ab}}$ \\
T5 & $0.54^{\mathrm{ab}}$ & $8.17^{\mathrm{d}}$ & $1.34^{\mathrm{d}}$ \\
T6 & $0.39^{\mathrm{bc}}$ & $37.64^{\mathrm{ab}}$ & $2.20^{\mathrm{a}}$ \\
T7 & $0.64^{\mathrm{a}}$ & $22.88^{\mathrm{bcd}}$ & $1.93^{\mathrm{abc}}$ \\
T8 & $0.42^{\mathrm{bc}}$ & $17.54^{\mathrm{d}}$ & $1.81 \mathrm{~b}^{\mathrm{c}}$ \\
T9 & $0.36^{\mathrm{c}}$ & $23.27^{\mathrm{bcd}}$ & $1.89^{\mathrm{abc}}$ \\
Mean & 0.44 & 24.22 & 1.88 \\
SE & 0.09 & 8.21 & 0.20 \\
\hline
\end{tabular}

Values followed by the same letters in columns are not significantly different $(\mathrm{P}<0.05)$ Generalized Linear Model Procedure of Statistical analysis system (1999)

Table 4 Effects of organic and inorganic fertilizer on onion yield (ton $\mathrm{ha}^{-1}$ ) in the first and second year

\begin{tabular}{l|cc}
\hline \multicolumn{1}{c|}{ Treatment } & $2012 / 2013$ & $2013 / 2014$ \\
\hline T1 & $24.00^{\mathrm{e}}$ & $21.75^{\mathrm{d}}$ \\
T2 & $36.75^{\mathrm{d}}$ & $41.50^{\mathrm{c}}$ \\
T3 & $64.25^{\mathrm{a}}$ & $60.35^{\mathrm{a}}$ \\
T4 & $39.75^{\mathrm{cd}}$ & $43.25^{\mathrm{c}}$ \\
T5 & $37.75^{\mathrm{d}}$ & $44.00^{\mathrm{bc}}$ \\
T6 & $62.00^{\mathrm{a}}$ & $61.11^{\mathrm{a}}$ \\
T7 & $49.75^{\mathrm{b}}$ & $47.10^{\mathrm{bc}}$ \\
T8 & $37.75^{\mathrm{d}}$ & $49.25^{\mathrm{bc}}$ \\
T9 & $43.25^{\mathrm{c}}$ & $51.75^{\mathrm{b}}$ \\
Mean & 43.92 & 46.67 \\
SE & 25.53 & 44.17 \\
\hline Values followed by the same letters in columns are not significantly different $(\mathrm{P}<0.05)$ Generalized Linear Model Procedure of Statistical analysis \\
system (1999)
\end{tabular}

Lowest nutrient uptake by onion bulbs was recorded in the control plot in both years. This may be due to greater availability of nutrient particularly $\mathrm{N}$ with the treatment application. Coolong et al. (2004)) reported that increased $\mathrm{N}$ and increased rate of sheep and chicken manures increased onion $\mathrm{N}$ content. They attributed the increase to the availability of soil N. Similar results were reported by Halvorson et al. (2002). They linked the result to the supply and availability of nutrients to organic manure. However, this study contradicts Yoldas et al. (2011) who reported decreased onion $\mathrm{N}$ content with increasing $\mathrm{N}$ rates and linked results to dilution effects

The higher $\mathrm{P}$ uptake recorded with combined inorganic and organic fertilizers of sheep manure may be attributed to improved $\mathrm{P}$ efficiency as a consequence of organic matter addition. Rengel (2002) indicated that one of the three broad categories of P efficiency mechanism is associated with microorganisms which are enhanced in the presence of organic matter. With increased mineralization, there is enhanced $\mathrm{P}$ uptake by the crop. It may also be attributed to increased nitrogen availability in the soil with consequential effects of rapid vegetative growth and P uptake. Jerell and Beverly (1981) reported that the concentration of $\mathrm{P}$ in plants increased as plant responded to applied $\mathrm{N}$ which was attributed to increased growth, improved energy supply to roots and generally better plants health. Kumar et al. (2006) found that phosphorus content of bulb was increased over the control with the application of $150 \mathrm{kgha}^{-1}$ of $\mathrm{N}$. Coolong et al. (2004) obtained similar result and reported that $\mathrm{N}$ and $\mathrm{P}$ content of onions increased with $\mathrm{N}$ levels and was linked to $\mathrm{N}$ availability. In the second year, highest $\mathrm{P}$ uptake by onions was recorded in the control plot. This may be due optimum $\mathrm{P}$ concentration in soil prior to treatments application as shown on Table 1. Abdulrazzag (2002) reported a decrease in $\mathrm{P}$ uptake by onions with increasing levels of sheep and chicken manure which was attributed to fixation of surplus $\mathrm{P}$ by organic manure

Higher $\mathrm{K}$ uptake with the application of sheep and poultry manures singly, and in combination, and combined poultry litter and inorganic fertilizer, may be connected to higher K content of the manures. Shedeen et al. (2014) attributed increased $\mathrm{K}$ uptake to organic manure supplying a variety of soil nutrients and promoting growth and nutrients absorption. Yoldas et al. (2011) reported that a rise in $\mathrm{K}$ content in bulbs depend on cattle manure rate. However, this is contrary to Abdelrazzag (2002) who reported increased onion K uptake at lower treatments levels and attributed it to dilution effect.

Increased total yield in the second year (Table 4) could be attributed to residual effect of added organic manure. Carol et al. (1999) and Kwaghe et al. (2015) reported higher yield in subsequent season and linked it to the ability of applied organic manure to retain nutrients 
over a long period of time with minimal leaching problems compared to that of inorganic fertilizer alone.

\section{Conclusion}

Application of organic and inorganic fertilizers improved soil porosity, some chemical properties and generally fertility status of the soils. It significantly influenced uptake of nitrogen, phosphorus and potassium by red onion. Nitrogen and $\mathrm{K}$ uptake increased with increasing treatment levels. However, $\mathrm{P}$ uptake was highest at lower treatment levels and could be linked to sufficiency of indigenous soil $\mathrm{P}$ for plant growth resulting in high $\mathrm{P}$ uptake with minimal nutrient inputs. Integrated nutrient management improved $\mathrm{N}$ and $\mathrm{K}$ uptake by red onions in soils of Moda-Michika where $\mathrm{P}$ is not a limiting nutrient. Similarly, higher yield was recorded with combined organic and inorganic fertilizer application and therefore INM should be adopted to improve the productivity of onions in the soils of Moda-Michika and similar soils. However, further research should be carried to measure the nutrient use efficiency of these soils.

\section{References}

Abdelrazzag A. 2002. Effect of chicken manure, sheep manure and inorganic Fertilizer on yield and Nutrient uptake by onion. Pakistan Journal Biological Science 5(3): 266-268.

Aisha AH, Rizk FA, Shaheen AM, Abdel-Mouty MM. 2007. Onion plant growth, bulbs yield and its physical and chemical properties as affected by organic and natural fertilization. Research Journal of Agriculture and Biological Sciences, 3(5): 380-388.

Brady NC, Weil RR. 2008. The Nature and Properties of Soils (14 ${ }^{\text {th }}$ ed). Prentice Hall Inc. New Delhi.

Bray RA, Kurtz LT. 1945. Determination of Total and Available Forms of Phosphorus In: Soil Science38: 617-628.

Carol M, Tanya C, Tamera F.1999. From end to begging: A Manure Resource Guide for farmers and gardeners western Washington. King Conservation District 935 Powell Ave SW Renton, Washington D.C., USA.

Coolong W, Kopsell T, Kopsell DA, Randle DM. 2004. Nitrogen and sulphur influence nutrient usage and accumulation in onion (Allium cepa L.). Journal of plant Nutrition. 27(9): 1667-1686.

Epstein E. 1972. Mineral nutrition of plants: Principles and perspectives. John Wiley and sons, London.

Halvorson AD, Follet RF, Bartolo ME, Schweissing FC. 2002. Nitrogen fertilizer use efficiency of furrow-irrigated onion and Corn. Agron. J., 94: 442-449.

Havlin J, Beaton JD, Tisdale SL, Nelson WL. 1999. "Soil fertility and fertilizer". $6^{\text {th }}$ ed. Prentice Hall, New Jersey.

Hossain AKMAR, Isalm J. 1994. Status of Allium production in Bangladesh. Acta Horticulture 358: 33-36.

Jaiswal PC. 2004. Soil, Plant and Water Analyses. Kalyani Publishers Ludhiana, New Delhi - Norda Hyderabab, India. Jerell, W. M. And R. B. Beverly. 1981. The dilution effect in plant nutrition studies. Advances in agronomy, 34:197-224.

Kumar S, Tiwari CP, Singh V. 2006. Bulb yield and quality of onion (Alluim cepa L.) as affected by application rates of $\mathrm{N}$ and potassium fertilizer. Agric. Sci. Digest. 26(4): 11-14.
Kwaghe E K, Saddiq AM,Solomon R I, Musa SA. 2015. Effects of organic and inorganic fertilizers on the growth and yield of red onion (allium cepa 1.) in michika, northern guinea savannah, Nigeria. Internal Journal of Innovative Research and Development, 4 (13):342-347. http:/www.ijird.com

Lal R. 1985. A soil suitability guide for different tillage systems in the Tropics. Soil and Tillage Research. 5:179-196.

Magdi A, Mousa A, Mohamed FM. 2009. Enhanced Yield of Onion (Allium cepa L. Cv Giza 6) Produced Using Organic Fertilization. Ass. Vniv. Bulletin of Environ. Res. 12 (1): 1-9.

Messiaen CM, Rouamba A.2004. Allium cepa L. [Internet] Record from Protabase. Grubben, G.J.H. and Denton, O.A. Plant Resources of Tropical Africa/Ressources of Tropical Africa/ Major Food and Agricultural Commodities and ProducersCountriesByCommodity.Wageningen,Netherlands.http://databa se.prota.org/search.htm

Mirza H, Ahmed KU, Nahar K, Akhter N. 2010. Plant growth pattern, tiller dynamics and dry matter accumulation of wetland Rice (Oryza Sativa L.) as Influenced by application of different manures.Nature and Science 8(4): 1-10. http://www.sciencepub.net/nature

Misra U K, Das N. 2000. Phosphorus availability to maize as influenced by organic amendments. Journal of Indian Society of Soil Science 48(2):298-305.

National Gardening Association. 2015. Food gardening guide 237 Commerce, St Suite 101, Williston, VT.

Podmore L. 2009. Irrigation salinity causes and impacts. Prove fact 937. Department of industry and investment, New South Wales, Australia. http:www-dpi-nsw.gov.au/print fact.

Rengel Z. 2002. Mechanistic Simulation Model of Nutrient Uptake: A Review. Plant and Soil 152:161-173.

Rengel Z. 1993. In: Mineral Nutrition of Crops: Fundamental Mechanism and Implication. CBS Didil. Edist New Delhi, India.

Sanchez PA, Mokwunye AU, Kwesiga FR, Ndiritu CG, Woomer PL. 1997. Soil fertility replenishment in Africa: An investment in natural resource capital replenishing soil fertility in Africa. Soil society of America special publication. No. 51. Madison, USA.

Sillanpa'a M. 1992. Micronutrients and the Nutrient Status of Soils: A Global Study. FAO Soil Bulletin 48. Osakeyhtio. Finland.

Squire GR. 1993. The Physiology of Tropical Crop Productions $\mathrm{CAB}$, Wallingford- Oxon, UK.

Statistical Analysis System (SAS). 1999. SAS/Stat. User's guide version 8, SAS Institute Inc. Cary NC, USA.

Stewart MW, Dibb WD,. Johnston EA, Smyth JT. 2005. The contribution of commercial fertilizer nutrients to food production. Agronomy Journal. 97:1-6.

Suresh KD, Sneh G, Krishn KK, Mool CM. 2004. Microbial biomass carbon and microbial activities of soils receiving chemical fertilizers and organic amendments. Archives Agronomy Soil Science, 50: 641-647.

Trehan SP. 1997. A rapid method for the estimation of potential immobilization of $\mathrm{N}$ alter the addition of cattle slurry to soil $\mathrm{J}$ Indian Soc. Soil Sci. 45: 14-19.

Woomer PL, Swift ML. 1994. The biological management of tropical soil fertility. John Willy and Sons, New York.

Wortmann CS, Mamo M, Shapiro CA. 2009. Management strategeies to reduce rate of soil acidification. University of Nebraska Lincoln Extension, Institute of Agriculture and Natural Resources.Lincoln, NE. http://www.Ianrpubs.Unl. edu/epublic/live/ g1503/build/target 6 .

Yoldas F, Ceylan S, Mordogan N, Esetlili BC. 2011. Effect of organic and inorganic fertilizers on yield and mineral content of onion (Allium cepa L.). African Journal of Biotechnology 10(55): 11488-11492. 